\title{
Game Model Based on Environment Insights for Elementary School Children (6-12 Years)
}

\author{
Marlinda Budiningsih ${ }^{1}$, Nofi Marlina Siregar ${ }^{2}$, Hernawan $^{3}$ \\ 1,2,3 Faculty of Sports Science, Jakarta State University, Indonesia \\ mbudiningsih@unj.ac.id
}

\section{Abstract}

This study aims to create a product in the form of a game model based on environmental insights for elementary school children. This research is a research development using research and development from Borg and Gall which consists of ten steps. In this study, researchers only used eight steps because after conducting a small group trial and product evaluation it was declared to be feasible for a primary trial or field trial by experts. This study involved 80 subjects aged 6-12 years. Data collected through observation, interviews, and tests.The significant value of the difference in the results of $t$-count $=28,971$, and $p$-value $=0.00$ $<0.05$, which means there is a significant difference in understanding of environmental insights before and after being treated in the form of a game model based on environmental insights. It was concluded that the game model developed was effective in increasing understanding of environmental knowledge for children aged 6-12 years.

Keywords

games, environmental

insight, elementary school

children (6-12 years)

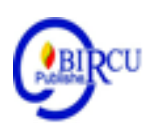

\section{Introduction}

Environmental education is one important factor to minimize environmental damage that occurs. Environmental education is carried out as an effort to increase understanding and care in finding solutions and preventing the emergence of environmental problems. Environmental education carried out in educational institutions will not change the situation and conditions that are damaged for the better in a short time, but rather requires a relatively long time with processes and resources that consistently support the preservation of the environment. Therefore, efforts are needed to raise awareness of environmental concerns, instill understanding of the problem, and foster a sense of ownership and participate in maintaining the natural resources around it to stay beautiful and healthy (Djanius, 2012).

Various studies and studies have been carried out and believe that the high increase in community needs is directly proportional to the exploitative behavior towards meeting those needs. The tendency of exploitative behavior is reflected in the decreasing level of quantity and quality of the available natural resources (Wong et al., 2018). Therefore, human quality becomes a central issue in efforts to save natural resources because with better environmental knowledge, it is expected that all elements of the public are aware to take part in efforts to save and preserve the environment.

The government, in this case represented by the State Ministry of Environment together with the Ministry of National Education, the Ministry of Religion, and the Ministry of Home Affairs in February 2004, has established a policy on environmental education. The predetermined policy is a basic policy as a direction for all stakeholders in the implementation and development of environmental education in Indonesia (Otto, 2015) . Through this provision, it is hoped that alternative solutions are effective and efficient in an 
effort to increase public knowledge and understanding of the preservation of environmental functions. Environmental education in Indonesia so far has not been able to provide a positive influence on changes in public awareness and behavior in carrying out conservation actions and activities that are environmentally friendly (Richard, 2017) .

\section{Review of Literature}

In 2006 the Ministry of Environment launched the Adiwiyata Program, a program that aims to encourage and shape schools in Indonesia so that they can take part in implementing government efforts towards environmental preservation and sustainable development for the interests of present and future generations. (Adam, 2014).

Another study from Ahmad (2014) in the Analysis Analysis of Implementation of Environmental-Based Curriculum Policy in the Adiwiyata Mandiri Program at SDN Dinoyo 2 Malang stated that environmental education conducted at school is beneficial so that teachers always make optimal efforts to always pay attention to their students with instill in students to be aware of caring and cultured in the school environment. The conclusion was added by the Thesis conducted by Heppyan Redy with the title Evaluation of the Application of Environmental Insight Curriculum in Middle School Level in 2016. Redy stated that the learning system based on environmental themes is considered to make it easier for teachers to instill environmental care characters in students and also can improve the quality of teaching and learning activities in class. Environmental education makes it easier for students to understand lessons, teacher skills become better, mastery learning increases and more capable of realizing environmental cultured schools if delivered thematic methods with a complete understanding of concepts for students (Murdiyanto, 2013; Pratomo, 2006; Affandi, 2013).

The introduction of environmental education in children is needed early for the formation of his personality later, so that the creation of a community that cares about the environment. The environment is one source of learning for children. Children learn from the environment such as parents, teachers, friends, pets, plants and so on that they can meet in daily life (Kozier \& Synder, 2011) . Environmental education that is instilled in children aims to enable children to get to know, have experience in exploring, have gratitude, care and responsibility to care for and preserve the environment in the long run.

Elementary school age children are children with a lot of age who experience drastic changes both mentally and physically. Elementary school children aged 6-12 years. Characteristics of children aged 6-12 years according to Hurlock in Novianti (2009) are as follows; a) a group period in which the children's primary attention is focused on the desires of the group; b) the process of adjusting to the standards agreed by the group; c) creative age, showing that children when not blocked by environmental obstacles, criticism, ridicule from adults then the child will exert his energy in creative activities; d) age of play because of the broad interests of children. Santrock added in Novianti (2009) that the characteristics of development in the middle and end are as follows: a) physical (body) changes in children among the important aspects of change in this period are the skeletal system, muscular system, and motor skills; b) analyze words and visualize in their imagination; c) have creativity; d) establish relationships with friends.

The most vulnerable pattern of child development is the age of 10-12 years because they are in pre-adolescent development which is physically and psychologically facing puberty. In this period the development of physical, cognitive, emotional, mental, and social aspects of children requires a way of conveying and the intensity of knowledge about sex and 
reproductive health that is different from other stages of the period ( Kurniawan , 2010 ; Behrman, Kliegman, \& Arvin , 2018 ).

Based on the characteristics of children aged 6-12 years. So the researchers decided to make observations in three elementary schools. The results of the observation were deepened with interviews with the teachers who were responsible for implementing the learning of Environmental Education or Healthy and Clean Living. The results of these observations concluded that the activities of teachers in delivering Environmental Education material still use conventional methods despite using up to date media (Piaget, 2014). Given the characteristics of children aged 6-12 years who are active, the researcher asks the teacher's response if an environmentally friendly game model is held that can be used in learning. 95\% of teachers answered agree and 5\% disagreed because the age was not young. The comparison of learning environmental education is carried out conventionally and a game model based on environmental insight briefly is; conventional learning is free, less attractive, less structured, not patterned, the atmosphere of learning is boring, while the game based on environmental insight is more interesting, systematic, structured, patterned, pleasant atmosphere, and environment-based (Flower, 2015) (Heppyan, 2016) .

Based on the learning differences that have been explained that the resulting model is expected to be able to stimulate the physical-motor, form courage and confidence, and increase environmental knowledge that can be implemented in everyday life. The teacher is expected to be able to organize a game model based on environmental insights in teaching and learning activities so that all children have good play experience and environmental knowledge and can be applied in their neighborhood.

\section{Research Methods}

The research is focused on developing an environmentally friendly game model with a mixed methods research approach that combines qualitative and quantitative methods. The method used in this study is a research and development ( research and development) from Borg and Gall (Walter \& Merridith, 2011). This research was conducted at the Primary School in the City of East Jakarta Administration. The study took sixteen weeks . The study was conducted in three elementary schools in East Jakarta with the total number of children aged 6-12 years involving 80 children from three different elementary schools in East Jakarta.

The collection of data in this study using (1) c otes field, to record the results of observation. (2) Questionnaire, as an expert test instrument as well as small group tests and field trials, (3) Performance tests, conducted by children to obtain results on the effectiveness of environmentally oriented game play using the Guttman scale to assess work results with a "score of 1 "For children to understand the meaning of the game properly and correctly, and" score 0 "for children who do not understand the meaning of the game correctly. The assessment results are then converted into a score and the percentage is calculated. After that it can be concluded the results are feasible or not the model.

The data obtained were in the form of qualitative data and quantitative data. Qualitative data were analyzed at the time of data collection in progress and after completion of data collection in the period, which in node $\mathrm{k}$ 's and the verification that the new findings in the form of description. Quantitative data were analyzed using descriptive analysis technique with percentage and pre-post test results of understanding of environmental education were analyzed by t-test (t-test). To determine the feasibility of the game model based on environmental insights, a questionnaire was given for the assessment of experts and teachers 
in the field test. The questionnaire used in the study used the Guttman measurement scale with two choices of feasible or improper answers.

\section{Discussion}

The results of the research in the existing stages begin with data collection through needs analysis and planning for model development, as well as making an initial draft of a game model based on environmental insights for elementary school children (ages 6-12 years), the next step is to conduct an expert test where the goals to be achieved namely obtaining the feasibility or validity of the model created by direct assessment from experts. Furthermore, the results of the expert material test used as a whole can be tested with a calculation result of $86.3 \%$, which means "feasible to use" .

The small group co-test involved 20 subjects with the criteria as explained in the first stage of the revision. After the results of the model are tested in small groups and have been evaluated, then the large group test. Continued testing in a large group with 80 subjects consisting of ages 6-12 years involving 80 children from three different elementary schools in East Jakarta. In testing the effectiveness of the model using SPSS 23.0 , the average value of understanding environmental education before being treated with the model is 61.0455. After being given the same treatment it becomes 75,590. This means that the greater the average score, the increase in understanding of environmental education. This can be seen in Table 1

Table 1. Average Value Table

\begin{tabular}{|c|c|c|c|c|}
\hline & $\begin{array}{c}\text { The } \\
\text { mean }\end{array}$ & N & $\begin{array}{c}\text { Std e . } \\
\text { Dev }\end{array}$ & $\begin{array}{c}\text { Std. Error } \\
\text { Mean }\end{array}$ \\
\hline Pre & 61,0455 & 80 & 3.285 & .495 \\
\hline Post & 75.5909 & 80 & 2.801 & .423 \\
\hline
\end{tabular}

Afterwards, the correlation coefficient calculation will be generated, based on the results of the output table 2. The correlation coefficient of the game understanding of environmental education before and after treatment is 0.411 with a p-value of $0.00<0.05$, so the conclusion is significant. This can be seen in Table 2 .

Table 2. Table Value Correlation (Paired Samples Correlations).

\begin{tabular}{|c|c|c|c|}
\hline Pairs & $\mathrm{N}$ & Correlation & Sig. \\
\hline Pre \& Post & 80 & .411 & .006 \\
\hline
\end{tabular}

The significance value of the difference in research uses the significance difference test with SPSS 23.0. In the results of the t-test $=28,971, \mathrm{db}=39$ and $\mathrm{p}$-value $=0.00<0.05$, this means that there is a significant difference in understanding of environmental education before and after being treated in the form of a game model based on environmental insight. It can be said that the game model of understanding environmental education developed is effective and can also improve understanding of environmental education. This can be seen in the following table 3 . 
Table 3. Difference Value (Paired Samples Test)

\begin{tabular}{|c|c|c|c|c|c|c|c|}
\hline \multicolumn{5}{|c|}{ Paired Beginning \& Final Differences } & \multirow{3}{*}{$\mathrm{t}$} & \multirow{3}{*}{ df } & \multirow{3}{*}{$\begin{array}{l}\text { Sig. (2- } \\
\text { tailed) }\end{array}$} \\
\hline \multirow{2}{*}{$\begin{array}{l}\text { The } \\
\text { mean }\end{array}$} & \multirow{2}{*}{$\begin{array}{l}\text { Std. } \\
\text { Dev }\end{array}$} & \multirow{2}{*}{$\begin{array}{l}\text { Std. } \\
\text { Error } \\
\text { Mean }\end{array}$} & \multicolumn{2}{|c|}{$\begin{array}{l}95 \% \text { Confidence } \\
\text { Interval } \mathrm{f} \text { the } \\
\text { Different }\end{array}$} & & & \\
\hline & & & Low w er & Upper & & & \\
\hline $\begin{array}{c}1.45 \\
2\end{array}$ & 3.331 & .502 & 15.55 & 13.53 & 28,971 & 38 & .000 \\
\hline
\end{tabular}

The rest of the data presentation with a comparison of the average understanding of environmental education and before and after treatment can be examined in the following diagram.

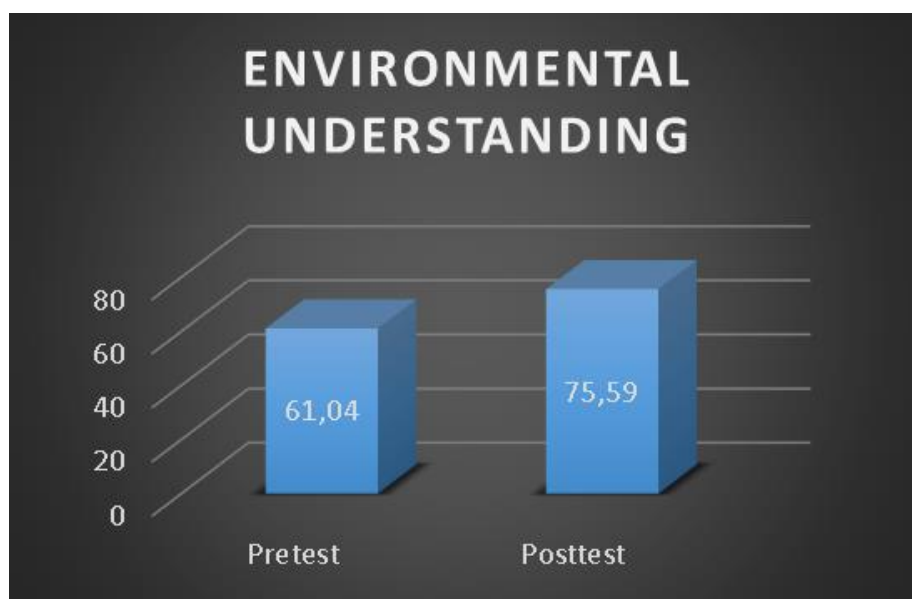

Figure 1. Pre-Post Test Value for Environmental Understanding

The data above, the results of small group trials and large group trials can be concluded that the game model based on environmental insights can be used in the teaching of children aged 6-12 years and is effective in increasing understanding of environmental education. There is a comparison of numbers which shows that the results of the initial test and the final test are experiencing an improvement, from the initial test on average with a value of 61.04 then given treatment in the form of game models based on environmental insights that have been developed and then held a post test to determine the effectiveness of the model developed and obtained an average value of 75.59 data.

The results of the study with the model output items ermainan -based insight into the environment is designed with the advanced aspects of motor skills in coordinating penemp atan position players for ages $6-12$ years. Systematically students of this age will do active things to feel themselves happy with the transfer of certain movements. Characteristics of children of this age have a tendency to play together in the sense of hanging out for certain goals. A teacher when giving motion learning needs to have extensive knowledge and creativity in conceptualizing teaching offerings in this case is a game based on environmental insights. 


\section{Conclusion}

No corresponding research results are assessed concluded tealah bahwasannya $\mathrm{p}$ enelitian This results in a product form for ecologically based game model for elementary school children (ages 6-12 years). The research developed has proven to be effective in increasing understanding of environmental insight knowledge of children aged 6-12 years. Overall, it can be proven that the product model in this study is feasible and effective to be used in learning environmental education for elementary school children. Therefore, this game model can be considered by teachers, parents as an alternative model of environmental education learning for elementary school children.

\section{References}

Adam, Ahmad Fajarisma Budi . 2014. Analysis of Implementation of Environmental-Based Curriculum Policy in the Adiwiyata Mandiri Program at SDN Dinoyo 2 Malang . Journal of Education Policy and Development 2 (2) 166-173

Affandi, R. 2013. Integration of Environmental Education through Social Studies Learning in Primary Schools As an alternative to Creating Green Schools. Pedagogy 2 (1) 98108.

Behrman, Kliegman, \& Arvin. 201 8. Nelson Childhood Health . (15th ed., Vol. I) (Prof. Dr. Dr. A.Samik Wahab, SpA (K), Ed) Jakarta: EGC.

Djanius Djamin. 2012. Oversight and Implementation of environmental laws; A Social Analysis . Obor Indonesia Foundation: Jakarta.

Fowler, JW 2015. Stages of Faith: The Psychology of Human Development and the Quest for Meaning. New York: Harper \& Row.

Heppyan Redy, 2016. Evaluation of the Application of Curriculum with Environmental Insights at the Middle School Level. University of Lampung. Thesis. Not published.

Kozier, Erb, Berman \& Snyder. 2011. Nursing Fundamentals: Concepts, Processes, and Practices (7 ed, Vol. I). Jakarta: EGC

Kurniawan 2010. Waste Management in Indonesia. Available at: http://www.iec.co.id/berita/management-sampah-di-indonesia.com Accessed, 03 October 2018.

Murdiyanto H. 2013. Improving the Quality of Science Learning through environmentalbased inquiry strategies in fourth grade students of SD Negeri Tambakaji 03 . UNS. Press: Semarang.

Novianti, Langgersari Elsari, 2009. Social Development Paper on Homeschooling Children Elementary School Age (6-12 Years), Faculty of Psychology, Padjadjaran University, Bandung.

Piaget, Jhon. 2014. The Origin of intelligence in children . International Universities press, Inc.

Potter, P., \& Perry, A., 2015. Nursing Fundamental Textbooks: Concepts, Processes \& Practices (4 ed, Vol. I). Jakarta: EGC.

Pratomo, S. 2006. Thematic Learning Models in Environmental Education (PLH) in Primary Schools. UPI. Purwakarta.

Richard E Mayer \& Patricia A. 2017. Research on Learning and instructional . New York: Routledge; Taylor and Francis 
Subagio, R., Rihatno, T., Hernawan, I., \& Firdiansyah, B. VOLLEYBALL SMASH SKILL TRAINING MODEL USING RUBBER TIRE AIDS FOR STUDENTS OF SMK. Management Research, 6(10), 1-10.

Walter R. Borg and Meredith D Gall. 2011, Educational Research an Introduction . Longman; New York. H.

Wong, D. Hockenberry-Eaton, M. Wilson, D., Winkelstein, M. \& Schwartz, P. 2018. Wong's Pediatric Nursing Textbook (6th ed., Vol. I). Jakarta: EGC. 